\title{
Teaching NeuroImages: A diffuse infiltrating retinoblastoma
}

Céline Friang, MD, Georges Caputo, MD, Paul Freneaux, MD, and Augustin Lecler, MD, MSc Neurology ${ }^{\circledR}$ 2018;90:e357-e358. doi:10.1212/WNL.0000000000004855

Correspondence

Dr. Lecler

alecler@for.paris

Figure 1 Imaging

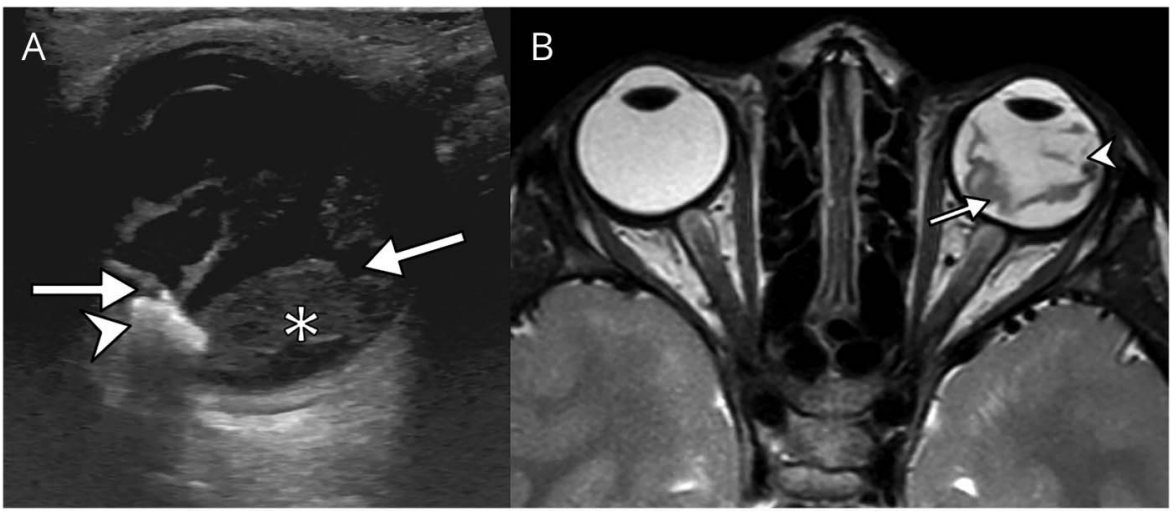

(A) Ultrasonography and (B) axial T2weighted MRI show a total retinal detachment (arrows) with a coarse nodular calcification on a thickened retinal fold (arrowhead) and a subretinal hemorrhage (asterisk).

A 4-year-old girl was referred for a painless heterochromia iridis and a loss of visual acuity. Funduscopic examination revealed a total retinal detachment $(\mathrm{RD})$ associated with a vitreous hemorrhage.

Ultrasonography and an ocular MRI showed a total $\mathrm{RD}$ with a calcification on the temporal retinal fold (figure 1), suggestive of a diffuse infiltrating retinoblastoma.

\section{MORE ONLINE}

$\rightarrow$ Teaching slides:

links.lww.com/WNL/A129

Figure 2 Histology

$\underline{5 \mathrm{~mm}}$

Histology shows a diffuse infiltrating retinoblastoma.

From the Departments of Ophthalmology (C.F., G.C.) and Radiology (A.L.), Fondation Ophtalmologique Rothschild; and Department of Pathology (P.F.), Institut Curie, Paris, France. Go to Neurology.org/N for full disclosures. Funding information and disclosures deemed relevant by the authors, if any, are provided at the end of the article. 
An enucleation was performed and pathologic examination confirmed the diagnosis of a differentiated diffuse infiltrating retinoblastoma (figure 2). This entity is rare but must be suspected in case of a calcified retinal detachment in a young child. $^{1,2}$

\section{Author contributions}

A. Lecler and C. Friang: study concept and design; acquisition, analysis, and interpretation of data. P. Freneaux and G. Caputo: acquisition of data.

\section{Study funding}

No targeted funding reported.

\section{Disclosure}

The authors report no disclosures relevant to the manuscript. Go to Neurology.org/N for full disclosures.

\section{References}

1. Brisse HJ, Lumbroso L, Fréneaux PC, et al. Sonographic, CT, and MR imaging findings in diffuse infiltrative retinoblastoma: report of two cases with histologic comparison. AJNR Am J Neuroradiol 2001;22:499-504.

2. Shields CL, Ghassemi F, Tuncer S, Thangappan A, Shields JA. Clinical spectrum of diffuse infiltrating retinoblastoma in 34 consecutive eyes. Ophthalmology 2008;115:2253-2258. 


\section{Neurology}

\section{Teaching NeuroImages: A diffuse infiltrating retinoblastoma \\ Céline Friang, Georges Caputo, Paul Freneaux, et al. \\ Neurology 2018;90; $357-\mathrm{e} 358$ \\ DOI 10.1212/WNL.0000000000004855}

This information is current as of January 22, 2018

\section{Updated Information \& Services}

References

Subspecialty Collections

Permissions \& Licensing

Reprints including high resolution figures, can be found at: http://n.neurology.org/content/90/4/e357.full

This article cites 2 articles, 1 of which you can access for free at: http://n.neurology.org/content/90/4/e357.full\#ref-list-1

This article, along with others on similar topics, appears in the following collection(s):

\section{All Pediatric}

http://n.neurology.org/cgi/collection/all_pediatric

MRI

http://n.neurology.org/cgi/collection/mri

Orbit

http://n.neurology.org/cgi/collection/orbit

Ultrasound

http://n.neurology.org/cgi/collection/ultrasound

Visual loss

http://n.neurology.org/cgi/collection/visual_loss

Information about reproducing this article in parts (figures,tables) or in its entirety can be found online at:

http://www.neurology.org/about/about_the_journal\#permissions

Information about ordering reprints can be found online:

http://n.neurology.org/subscribers/advertise

Neurology ${ }^{\circledR}$ is the official journal of the American Academy of Neurology. Published continuously since 1951, it is now a weekly with 48 issues per year. Copyright Copyright ( 2018 American Academy of Neurology. All rights reserved. Print ISSN: 0028-3878. Online ISSN: 1526-632X.

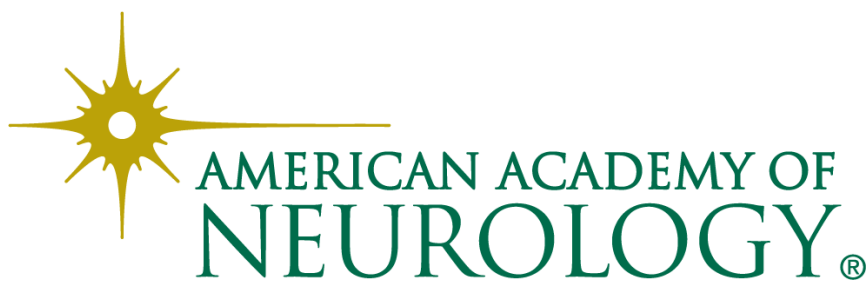

